Boletim IG, Instituto de Geocinências, USP, V. 11: 1-20, 1980

\title{
O GRUPO PINHAL NA REGIĀO NORDESTE DO ESTADO DE SĀO PAULO E ÁREAS VIZINHAS DO ESTADO DE MINAS GERAIS*
}

\author{
E. WERNICK \\ Dept? de Mineralogia e \\ Recursos Minerais \\ Instituto de Geociências \\ $e$ Ciências Exatas \\ Universidade Estadual Paulista \\ "Julio de Mesquita Filho"
}

\author{
F. PENALVA \\ Dept Q de Geologia Geral \\ Instituto de Geociências \\ Universidade de São Paulo
}

\begin{abstract}
E. Wernick and F. Penalva - The Pinhal Group in the NE of the State of São Paulo and SSW of the State of Minas Gerais, southern Brazil. Bol. IG., Instituto de Geociências, USP, V. $10: 00$ - 00, 1979.
\end{abstract}

The Pinhal Group is a very important lithostratigraphic unit that border the São Francisco Craton, in the NE of the State of São Paulo and SSW of the State of Minas Gerais, southern Brazil. The Pinhal and Socorro Complexes are the main granitic-migmatitic areas of this unit, including "migmatites forming granites", migmatites, "normal granites" and several medium to high grade metamorphic country rocks. The granitic suite include various equigranular and porphyroid types and porphyritic, pegmatitic and aplitic dikes. Geochronologic age determinations indicate their relation with "Brazilian Cycle" (Baikalian Cycle, of Upper Precambrian age); the country rocks belong to the Amparo Group (Middle Precambriam), which rocks underwent an intensive remobilization during the Brazilian Cycle.

* Trabalho realizado com auxílio do CNPq. 
The "migmatites forming granites" are surrounded by an aureole of migmatites composed of 3 zones: the outer zone is formed by layered migmatites, the medium one by agmatitic and "schollen" migmatites; and the inner one by "schlieren", nebulitic and homophanic migmatites. The central granitic core is equigranular or porphyroid.

The migmatitic aureole is frequently disturbed by faults, by "normal granite" instrusions or by the interference of adjacent aureoles; these disturbances lead to very complex (polyphasic) migmatites.

Strong metassomatic phenomena affected the rocks of the Pinhal Group, at two distinct phases. The first one, of potassic character, in characterized by an intensive development of microcline megacrystals; and the second one, of sodic nature, by the formation of pure albite. In each phase, distinct metassomatic pulsations have been observed, linked with the several intrusion and tectonic events which have affected the complexes which form megadiapirs of polydiapiric nature.

The big granite plutons have arisen from the base of the sialic crust along "thermal channels" related to zones of tectonic weakness. During this slow ascension these bodies have undergone deep modifications (remobilization, subsolidus recrystalization, metasomatism, assimilation and fractional crystalization), without significative changes in their chemical character.

From the regional point of view the Pinhal Group is correlated to the Serra dos Orgãos Group, in the Rio de Janeiro State.

Economic geology in the investigated region is mainly related to pegmatites exploitation.

\section{RESUMO}

O Grupo Pinhal é uma importante unidade litoestratigráfica, aflorante na região NE do Estado de São Paulo e SSW do Estado de Minas Gerais, no Brasil meridional. Os Complexos de Pinhal e Socorro são as principais áreas granítico-migmatíticas desta unidade, incluindo "granitos formadores de migmatitos", "granitos normais", migmatitos e vários tipos de metamorfitos regionais, de médio a alto grau de metamorfismo. $\mathrm{O}$ conjunto de rochas graníticas inclui diversos tipos equigranulares e porfiroides, bem como diques aplíticos, porfiríticos e pegmatíticos. A geocronologia indicou idades que relacionam essas rochas com o Ciclo Brasiliano (Ciclo Baikaliano, do Pré-Cambriano Superior); as rochas encaixantes pertencem ao Grupo Amparo (do Pré-Cambriano Médio), as quais sofreram uma intensa remobilização durante o Ciclo Brasiliano.

Os "granitos formadores de migmatitos" são circundados por uma auréola de migmatitos, composta por três zonas: a externa é formada por migmatito acamado; a intermediária, por migmatitos agmatítico e "schollen", e a interna por migmatito do tipo "schlieren", nebulítico e homofânico. $\mathrm{O}$ núcleo granítico central é equigranular ou porfiroide.

A auréola migmatítica é, com freqüência, perturbada por falhamentos, pela intrusão de "granitos normais" ou pela interferência de auréolas adjacentes; essas perturbações levam ao aparecimento de migmatitos complexos, polifásicos.

Intensa atividade metassomática afetou as rochas do Grupo Pinhal, em duas dases distintas. A primeira, de natureza potássica, é caracterizada pelo abundante desenvolvimento de megacristais de microlina, e a segunda, de natureza sódica, pela formação de albita pura. Em cada uma dessas fases observou-se pulsações metassomáticas distintas, relacionadas com as diversas intrusões e eventos tectônicos que afetaram os complexos que constituem megadiápiros de natureza polidiapírica.

Os grandes corpos graníticos plutônicos ascenderam, da base da crosta siálica, através de "canais térmicos" relacionados com zonas de fraqueza tectônica. Durante essa lenta ascensão, esses corpos sofreram profundas modificações (remobilizaçбes, recristalização sub-sólida, metassomatismo, assimilação e cristalização fracionada).

Do ponto de vista regional o Grupo Pinhal é correlacionável ao Grupo Serra dos Órgãos, no Estado do Rio de Janeiro.

Os recursos econômicos na região investigada constituem-se essencialmente de material para construção civil e minerais de pegmatito. 


\section{INTRODUÇÃO}

Grandes complexos granítico-migmatíticos ligados ao Ciclo Brasiliano ocorrem em toda região leste do Brasil, desde o Rio Grande do Sul até o Rio Grande do Norte. Os complexos situam-se tanto nas zonas de dobramento das Regiбes de Dobramento Nordeste (BRITO NEVES, 1975), Sudeste (ALMEIDA et al., 1976) e nos seus maciços medianos, quanto nas suas infraestruturas, que se estendem por toda faixa costeira, desde o Rio Grande do Sul até o Estado da Bahia (CORDANI, 1973; HASUI et al., 1975). Outra importante área de ocorrência constitui uma faixa que contorna a parte $\mathrm{S}$ do Craton de São Francisco, na porção N, NE e E do Estado de São Paulo e regiões vizinhas do Estado de Minas Gerais.

Nas primeiras ocorrências (zonas dobradas das Regiбes de Dobramento), os granitóides são envolvidos por encaixantes ectiníticas epizonais, geradas no Ciclo Brasiliano; nos demais casos as encaixantes geralmente são mais antigas, remobilizadas em grau variável no Pré-Cambriano Superior. É o caso, por exemplo, dos granitóides do Grupo Serra dos Órgãos, embutidos no Grupo Paraíba, de idade transamazonica (DELHAL et al., 1979; CORDANI et al., 1973).

É escopo do presente trabalho caracterizar os grandes complexos granítico-migmatíti$\cos$ da região NE do Estado de São Paulo e áreas vizinhas do sudoeste mineiro, que foram agrupadas sob a designação de Grupo Pinhal (WERNICK, 1977 a, b; 1978), os quais se acham embutidos, em sua maioria, em rochas do Grupo Amparo (WERNICK, 1965; EBERT, 1968) de idade transamazonica (WERNICK et al., 1976).

\section{OCORRÊNCIA E EXTENSÃO DO GRUPO PINHAL}

Na região em foco o Grupo Pinhal é representado por dois grandes complexos granítico-migmatíticos: Pinhal e Socorro (Fig. 1). O Complexo Pinhal situa-se a $\mathrm{N}$ da Faixa de Transcorrência de Jacutinga-Ipuiuna (WERNICK e PENALVA, 1973; PENALVA e WERNICK, 1973; EBERT, 1968; RODRIGUES,
1976), sendo encoberto a W pelos sedimentos da Sinéclise do Paraná; para leste estende-se até as proximidades da cidade de São João da Mata, MG. $\mathrm{O}$ seu limite $\mathrm{N}$ estende-se além das cidades de Botelhos e São José do Rio Pardo. Sua área de ocorrência é da ordem de $7.000 \mathrm{~km}^{2}$.

O Complexo Socorro situa-se a S da Faixa de Transcorrência de Inconfidentes (SOARES, 1976; WERNICK, 1977 b), desde as proximidades da cidade de Socorro, SP, até a E da localidade de Brasópolis, MG. Para S estende-se além das cidades de Bragança Paulista, e até as proximidades de Sapucaí Mirim e Campos do Jordão. Sua área de exposição, delimitada na Figura 1, é da ordem de $6.300 \mathrm{~km}^{2}$.

Uma expansão ocidental do Complexo Socorro constitui o Maciço de Morungaba, situado a $5 \mathrm{~km}$ deste complexo e com área aproximada de $330 \mathrm{~km}^{2}$ (WERNICK, 1972 a). Expansőes semelhantes, relacionadas ao Complexo Pinhal, ocorrem na sua porção N e NE, nas proximidades de São José do Rio Pardo, SP e Machado, MG.

\section{CONTATOS}

Os contatos dos Complexos Pinhal e Socorro com suas encaixantes são ora tectônicos ora intrusivos. O limite sul do Complexo Pinhal é dado pela faixa de Transcorrência de Jacutinga-Ipuiuna enquanto que na porção oriental é limitado, parcialmente, pela falha de empurrão de São João da Mata (BETTENCOURT, 1978); também parte do contato $\mathrm{N}$ é tectônico através da Falha de Divinolândia. Contatos intrusivos nítidos ocorrem a $\mathrm{N}$ e $\mathrm{NE}$.

$\mathrm{O}$ contato $\mathrm{N}$ do Complexo Socorro é dado pela Faixa de Transcorrência de Inconfidentes. Na parte oriental os contatos são tanto intrusivos quanto tectônicos, através de falhas normais e de empurrão (WERNICK, 1967), o mesmo ocorrendo em relação aos contatos sulinos e orientais. Os contatos intrusivos são concordantes ou discordantes, com desenvolvimento de brechas de contato e irradiação de corpos filonares através das encaixantes; observa-se, por vezes, o amarrotamento das encaixantes nas zonas de contato, alinhamento de minerais junto às bordas das intrusర̃es, bem como xenólitos em variados estágios de assimilação pelos granitóides (WERNICK, 1972 a). 


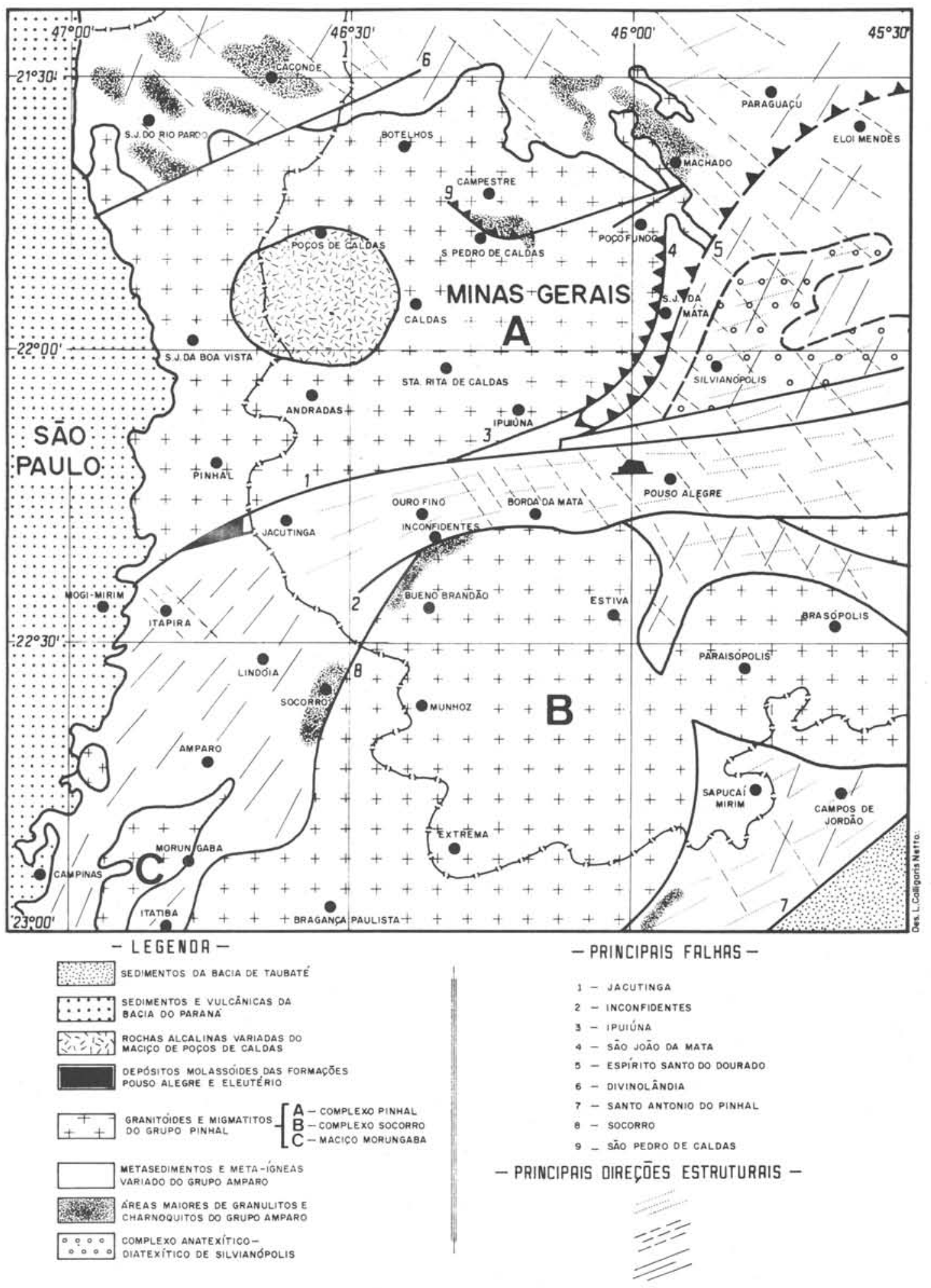

Fig. 1. MAPA GEOLÓGICO SIMPLIFICADO DA REGIĀO NORDESTE DO ESTADO DE SĀO PAULO E SUL DE MINAS GERAIS. (Segundo Fiori, Wernick e Bettencourt, 1978) 


\section{AS ENCAIXANTES}

As encaixantes dos complexos granítico-migmatíticos do Grupo Pinhal são representadas essencialmente pelo Grupo Amparo, uma unidade tipicamente metassedimentar referível ao Ciclo Transamazônico. O seu arcabouço litológico é dado por biotita e/ou hornblenda gnaisses, com predominância generalizada de plagioclásio; subordinadamente ocorrem gnaisses portadores de granada ou diopsídio.

As rochas exibem estrutura listrada, fitada ou bandeada e a textura geralmente é granoblástica-cataclástica. Também são freqüentes gnaisses anatexíticos e metatexitos, estes podendo evoluir até diatexitos e granitos autóctones, heterogêneos, com contatos difusos em relação às encaixantes. Nos metatexitos ocorrem estruturas "schollen", flebíticas, surreiticas, dobradas, estictolíticas, dictoníticas e ptigmáticas (MEHNERT, 1968), predominando as duas últimas. Nos gnaisses, gnaisses anatexíticos e metatexitos ocorrem intercalações mais ou menos possantes e frequentes de gnaisses graníticos, gnaisses porfiroblásticos, tipos variados de quartzitos e gonditos. Anfibolitos e hornblenditos, que localmente podem constituir a litologia predominante, exibem ampla variação de textura, estrutura e composição.

Ocorrem, ainda, rochas calcossilicatadas, raros mármores dolomíticos e variadas rochas granulíticas e charnockíticas. Metapelitos são representados por biotita $( \pm$ granada \pm sillimanita) gnaisses e xistos. Rochas ultrabásicas (dunitos, peridotitos, piroxenitos) ocorrem sob a forma de "sills" e diques, com raros leitos de cromititos e magnetitos. WERNICK (1978 a), reconheceu no Grupo Amparo pelo menos 10 associaçðes litológicas características, todas passíveis de mapeamento.

A litologia global do Grupo Amparo sugere um espesso pacote inicial de sedimentos clasto-psamíticos a pelíticos e clasto-químicos, predominantemente impuros, com intercalações de tufos e restritos sedimentos químicos; também ocorrem quantidades variáveis de corpos ígneos básicos e ultrabásicos plutônicos, hipoabissais e efusivos. Descriçбes mais ou menos pormenorizadas da litologia do Grupo Amparo são devidas a FRANCO e COUTINHO (1957), GOMES et al. (1966) WERNICK (1967, 1972 a, b, 1977, 1978 a), PIRES et al. (1970), OLIVEI-
RA (1973), OLIVEIRA e HIPPOLITO (1973), OLIVEIRA e ALVES $(1974,1976)$, WERNICK e ARTUR (1972 c) e WERNICK et al. (1976).

O metamorfismo do Grupo Amparo foi enérgico e de méđia a alta pressão, pertencendo suas rochas às fácies do anfibolito e granulito. WERNICK et al. (1976) e WERNICK (1977 a, 1978 a) mostraram, para esse Grupo, uma evolução policíclica, com base em dados geológi$\cos$, geocronológicos, litológicos e estruturais.

Nas imediaçбes de Eleutério (SP) e Jacutinga (MG) o Complexo Pinhal faz contato, através da Faixa de Transcorrência de Jacutinga, com o Grupo Eleutério, o qual por sua vez entra em contato com o Grupo Amparo através da zona brechada da Serra do Machado nas proximidades de Jacutinga (EBERT, 1971, 1974; WERNICK e PENALVA, 1974; RODRIGUES, 1976). O Grupo Eleutério corresponde a uma sequêencia molássica anqui- a epimetamórfica ligada ao Ciclo Brasiliano, equivalente à Formação Pouso Alegre (LEONARDOS JR. et al., 1971; HAMA e CUNHA, 1977).

\section{A CONSTITUIÇÃO DOS COMPLEXOS}

Os complexos granítico-migmatíticos integrantes do Grupo Pinhal são muito heterogêneos. Englobam vários tipos de rochas granitóides, ao lado de vastas áreas de migmatitos que resultam da injeção de material granítico de idade brasiliana nas litologias do Grupo de Amparo (HARME, 1965), ao lado de áreas constituídas principalmente por gnaisses, xistos, quartzitos, rochas calcossilicatadas, charnockitos e granulitos; estes constituem enclaves de até vários $\mathrm{km}^{2}$ no interior dos complexos e nas porções marginais chegam a constituir a litologia predominante (OLIVEIRA, 1973; OLIVEIRA e ALVES, 1974). Algumas vezes os metamorfitos estão preservados em "grabens", caso dos filitos do "graben" de Grama, a sul de São João da Boa Vista.

\section{AS ROCHAS GRANITOIDES}

Os granitóides do Grupo Pinhal são muito diversificados, incluindo termos equigranulares, de cor, composição e granulação variável, ao lado de granitos porfiróides. As rochas são isotrópicas ou orientadas e sua composição varia de quartzo diorítica a granítica (Fig. 2). Local- 


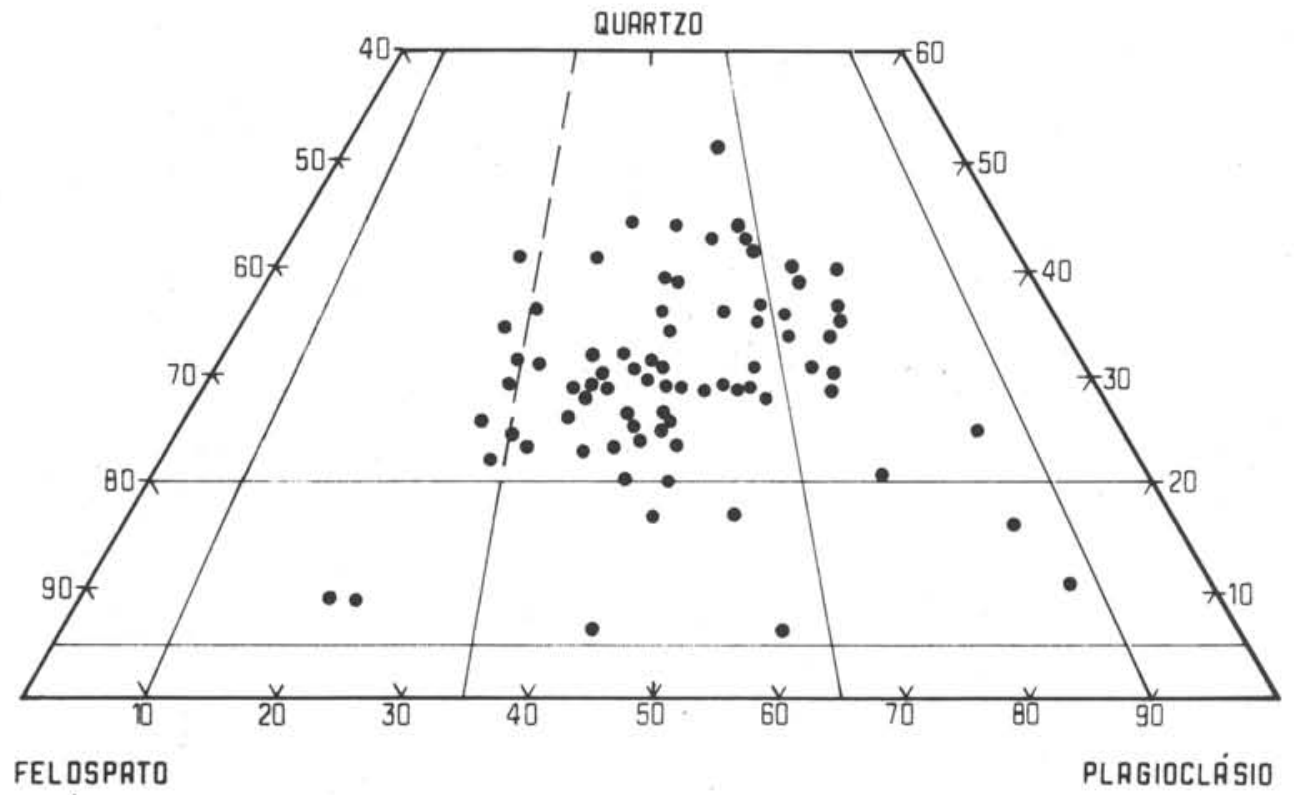

POTÁSSICO

Fig. 2 - COMPOSIÇĀO DOS GRANITOS PORFIRÓIDES DO GRUPO PINHAL

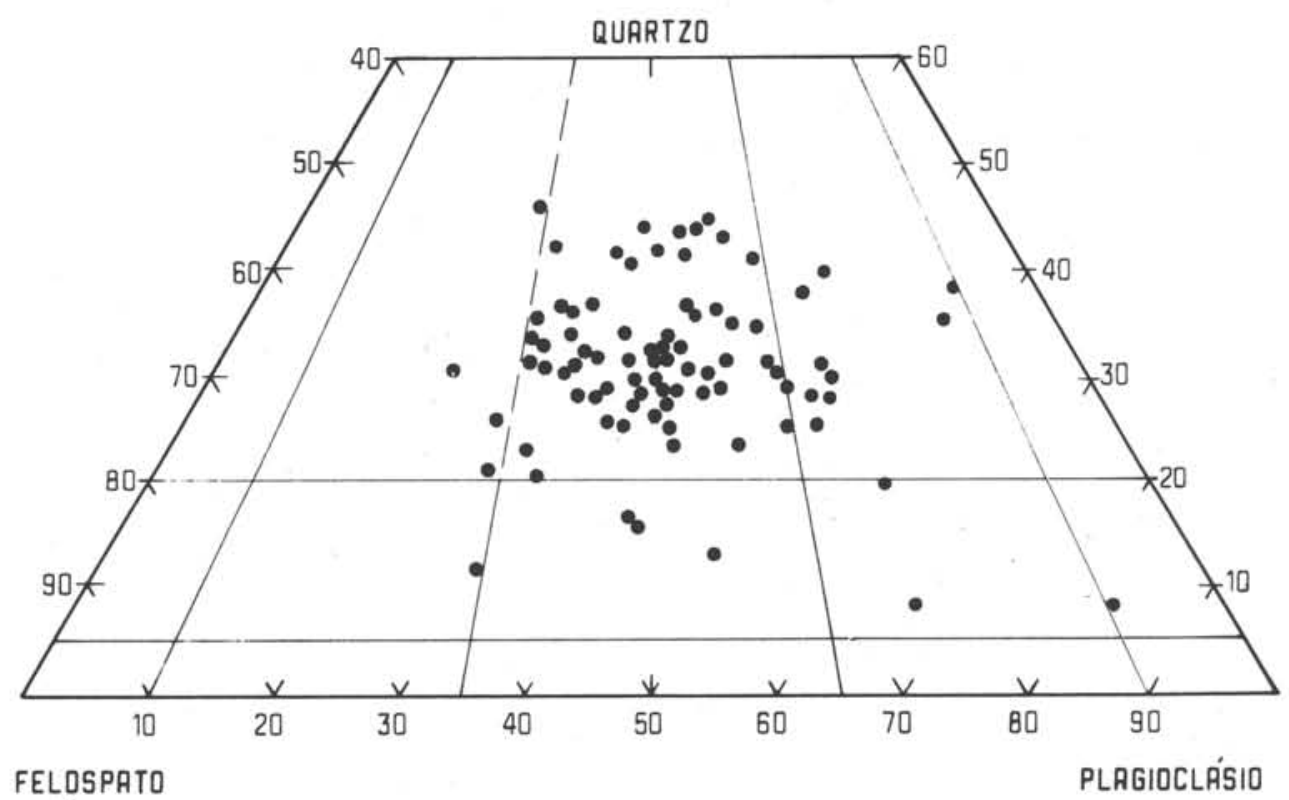

POTÁSSICO

Fig. 2 - COMPOSIC̄ĀO DOS GRANITOS EQUIGRANULARES DO GRUPO PINHAL 
mente ocorrem termos sieníticos e quartzo sieníticos que gradacionam para granitos ao aumentar o seu teor em quartzo. Formam manchas irregulares, difusas, gradacionais, nos granitos equigranulares. Ocorrem, ainda, pegmatitos, aplitos e granitos pórfiros, estes últimos podendo constituir "plugs" de reduzidas dimensбes.

\subsection{Granitos Porfiróides}

Megacristais - Nas rochas porfiróides os megacristais são predominantemente de microlina, ao lado de menores quantidades de oligoclásio, o qual pode mesmo faltar. São de cor rosada, cinza ou esbranquiçada; alcançam até $15 \mathrm{~cm}$ de comprimento e são retangulares, ovalados ou irregulares.

Alguns exibem delgado anel externo, branco, de albita ou oligoclásio. Quimicamente são caracterizados por elevados teores de $\mathrm{Or}$, sempre superior a 75\% (GOMES et al., 1976). São frequentes punctuaçōes escuras de biotita, algumas vezes formando até 3 anéis paralelos aos contornos externos dos megacristais; também são comuns as concentraçбes de biotita em torno dos megacristais, os quais não raro exibem geminação de Carlsbad e macropertita de veio e mancha.

A matriz que envolve os megacristais é hipoautomórfica granular, milimétrica, cinza ou rosada, de composição quartzo diorítica a granítica. Entre os granitos porfiróides a composição predominante é adamelítica, englobando variedades leuco- e mosocráticas (Fig. 2).

Os megacristais, observados ao microscópio, mostram inclusбes arredondadas ou irregulares de quartzo, de plagioclásio subhedral a anhedral, às vezes corroídos, nebulosos. As inclusões de biotita castanha, já mencionadas, englobam cristais diminutos de apatita, irregulares ou ovalados; minerais opacos são raros no interior dos megacristais.

As inclusర్es são mais frequentes nas partes periféricas dos megacristais e ocorrem tanto isoladas quanto formando pequenos agregados poliminerálicos, tratando-se, neste caso, de verdadeiras porçōes da matriz englobadas pelos grandes cristais. É comum a orientação das inclusð̄es paralelamente ao contorno destes cristais, os quais mostram, em alguns casos, expansб̄es irregulares que penetram nos interstícios entre os minerais da matriz circundante. Nas vi- zinhanças dos megacristais a granulação da matriz é nitidamente mais fina que nas demais porçб̄es da rocha; observa-se com freqüência que a biotita se amolda em torno dos megacristais.

Matriz - É composta principalmente por quantidades variáveis de quartzo, plagioclásio e microclina.

a. Quartzo - Ocorre sob forma anhedral, com extinção ondulante freqüente e rico em inclusões alinhadas. São comuns faixas de esmagamento recristalizadas e deformação do quartzo segundo o padrão "tabuleiro de xadrez".

b. Plagioclásio - E representado por oligoclásio ou andesina. Mostra tendência para idiomorfismo (a qual aumenta com a quantidade de plagioclásio na rocha), geminação polissintética cerrada e discreto zoneamento. Sericitização é comum, seja no mineral inteiro seja restrita ao seu núcleo.

c. Microclina - É mineral anhedral, com geminação em grade e micropertita de filme e veio. Nas rochas ricas em plagioclásio, ela ocupa posição intersticial, com os contatos se interpenetrando. Nas rochas ricas em microclina os grãos mostram contatos por justaposição, desenvolvendo verdadeira textura em mosaico. A composição dessa microclina é muito semelhante àquela dos megacristais (GOMES et al. 1976).

Em muitas oportunidades foi possível observar evidências de microclinização de plagioclásio da matriz, com o desenvolvimento de manchas irregulares ou retangulares de microclina, seja no interior ou nas margens dos grãos de plagioclásio. Ao aprofundar-se esta transformação, o plagioclásio torna-se cada vez mais nebuloso, sericitizado, epidotizado e rico em mirmequita.

Junto aos contatos entre microclina e plagioclásio, quer na matriz, quer no contato desta com os megacristais (ou ainda nas inclusర̃es nele contidas), é freqüente o desenvolvimento de mirmequita com formas arqueadas, cuja convexidade volta-se para a microclina. O quartzo da mirmequita exibe formas em U, Y, V, I ou S, sendo que nos três primeiros casos os ramos abertos estão dirigidos para a microclina. $\mathrm{O}$ plagioclásio mostra-se, nesses casos, corroído e com aspecto turvo. Mirmequita ocorre, també,. ao longo de alguns contatos entre quartzo e microclina. 
d. Máficos - Na matriz ocorre, ainda, biotita castanha em cristais tabulares ou "fiapos" irregulares, deformados pelos grãos vizinhos. Localmente mostra-se cloritizada (penina), seja totalmente ou apenas ao longo de seus contornos ou planos de clivagem. Essas biotitas contêm, em geral, diminutas inclusões de apatita, titanita, allanita e zircão. Hornblenda verde ocorre sob forma de grãos colunares ou irregulares, às vezes superando, em volume, a biotita. Sua percentagem é maior nas rochas ricas em plagioclásio. Quanto maior a taxa de microclina menor é o teor em hornblenda e o índice de coloração da rocha.

As relaçoes entre biotita e hornblenda são variáveis: ora ambos os minerais ocorrem isolados, ora estão associados, seja por contato periférico ou por intercrescimento. Neste caso a biotita forma uma coroa externa mais ou menos contínua (envolvendo os grãos de hornblenda) ou então situa-se ao longo dos planos de clivagem deste mineral. Em alguns casos ocorre aglutinação de opacos, zircão, titanita, hornblenda e biotita, constituindo agregados com dimensб์es variáveis.

Associa-se à hornblenda (às vezes) e ao plagioclásio (com freqüência) pistacita e clinozoisita, indicando claramente terem sido formadas às expensas daqueles minerais. Ainda entre os minerais secundários observa-se localmente a presença de raros carbonatos, associados principalmente aos plagioclásios saussuritizados. Grãos irregulares ou poligonais de opacos ocorrem dispersos pelas rochas ou, de preferência, associados aos ferro-magnesianos; alguns cristais maiores, esqueléticos, contêm inclusóes de plagioclásio.

\subsection{Granitos Equigranulares}

Os granitos equigranulares são de cor rosada, avermelhada, esbranquiçada ou cinzenta (clara ou escura). Sua granulação varia de fina a grossa, exibindo localmente feições pegmatóides, e sua composição varia de quartzo diorítica a granítica (Fig. 2). Do ponto de vista petrográfico às vezes assemelham-se aos diversos tipos de matrizes dos granitos porfiróides. É freqüente a ocorrência de grandes grãos arredondados de quartzo, indicando tratar-se de intrusões sub-vulcânicas, epizonais.
Granitos ricos em plagioclásio - Ao microscópio observam-se grandes diferenças entre os tipos ricos em plagioclásio (quartzo dioritos, granodioritos) e em feldspato alcalino (adamelitos, granitos). Nos primeiros a textura é panhipautomórfica granular, com a trama formada predominantemente por cristais subhedrais a anhedrais, retangulares, de plagioclásio com relação comprimento:largura da ordem de 3:2. Mostram núcleos homogêneos de andesina, com geminação polissintética, e envolvidos por delgado anel externo de oligoclásio (ou albita), límpido, homogêneo ou com cerrada geminação. A textura tende para equigranular, com freqüentes contatos por justaposição entre os grãos de plagioclásio. A taxa de máficos é variável, em geral superior a $10 \%$, muitas vezes ocorrendo agregados de hornblenda verde (em geral o máfico predominante), biotita castanha, apatita euhedral ou arredondada, titanita, zircão e opacos. Epidoto e mirmequita são raros e a microclina (anhedral e com geminação cruzada) ocupa posição intersticial. Os grãos de quartzo ora são grandes e arredondados, ora são intersticiais; neste caso têm formas poligonais, impostas pela malha de grãos de plagioclásio euhedrais. Raramente se observa extinção ondulante, inclusão "em cordões", bem como inclusões recíprocas entre os minerais constituintes da rocha.

Granitos ricos em microclina - Nos granitos equigranulares ricos em microclina a textura exibe forte tendência panxenomórfica granular, com características inequigranulares. É formada pelo intercrescimento íntimo de cristais subhedrais e anhedrais de microclina, plagioclásio e quartzo. São comuns os contatos por interpenetração, lobulados, serrilhados ou denteados, ao lado de freqüentes inclusões mútuas dos minerais formadores da rocha. O plagioclásio (oligoclásio) é zonado com geminação polissintética cerrada e sericitização preferencial ao longo de determinadas zonas de composição, levando, em alguns casos, ao desenvolvimento de anéis concêntricos de sericita, separados por anéis de material não alterado. O quartzo forma tanto grandes cristais arredondados quanto pequenos grãos anhedrais, irregulares, intersticiais; é rico em cordões de inclusões e a extinção ondulante é freqüente. Mirmequita é comum ao longo dos contatos entre plagio- 
clásio e microlina; esta ocorre sob forma de grãos anhedrais, quase sempre com geminação em grade e localmente mostra-se sericitizada.

Nas porçбes da rocha pobres em quartzo, os cristais de microclina adquirem formas poligonais e os contatos são por justaposição, desenvolvendo textura local em mosaico. Sua triclinicidade varia nos diferentes tipos litológicos (WERNICK e FERNANDES, 1972).

A taxa de máficos é pequena, predominando termos leucocráticos e alasquíticos. A biotita castanha, freqüentemente cloritizada, é o mineral ferro-magnesiano predominante, sendo rara a presença de hornblenda. Zircão, apatita, titanita, allanita e opacos são os acessórios mais comuns. O teor em epidoto é elevado, o qual é formado às custas de plagioclásio $\mathrm{e}, \mathrm{em}$ menor escala, da hornblenda. Minerais secundários são clorita, sericita e carbonatos.

\subsection{Granitos Pórfiros}

Macroscopicamente os granitos pórfiros são rochas compactas e homogêneas, compostas aproximadamente por $50 \%$ de fenocristais (de feldspato, quartzo e máficos), inseridos numa matriz densa. Essas rochas exibem cor cinza, avermelhada, amarelada ou acastanhada. Deformaçбes pós-tectônicas são freqüentes e levaram à transformação parcial dos fenocristais euhedrais de ortoclásio (com até $2 \mathrm{~cm}$ de comprimento) em microclina, a qual exibe a característica geminação em grade. Também os raros fenocristais euhedrais de plagioclásio (An 25) mostram sinais de deformação, através de grãos fraturados ou planos de geminação polissintética encurvados.

Os fenocristais de quartzo exibem forte extinção ondulante e zonas de esmagamento microgranuladas. São comuns sinais de corrosão magmática, bem como algumas formas bipiramidais (indicando quartzo de alta temperatura); no entanto, predominam grãos arredondados que atingem até alguns $\mathrm{mm}$. Os fenocristais de máficos são diminutos e raros, representados pela augita e biotita castanha (esta em parte cloritizada).

A matriz é de granulação fina a densa e composta principalmente por mistura íntima de quartzo e feldspato potássico, tendo como acessórios hornblenda, augita, titanita, zircão e opacos.

\subsection{Aplitos}

Os granitos aplíticos são caracterizados por mineralogia bastante simples, contendo quase que somente microclina e quartzo. Os raros acessórios se constituem de plagioclásio (An 23), opacos, moscovita e epidoto. A textura é equigranular, panxenomórfica aplítica, caracterizada pela intima interpenetração dos minerais constituintes da rocha.

Os aplitos formam diques, lentes, veios ou bolsões, com espessura de até um metro e suas cores são claras, avermelhadas, amareladas, cinzentas ou esbranquiçadas.

WERNICK (1972 c) concluiu, ao estudar as relações entre os granitos equigranulares, granitos pórfiros e aplitos, que os mesmos pertencem a uma única seqüência magmática evolutiva, os três membros caracterizando-se por um sucessivo incremento em feldspato potássico e quartzo.

\subsection{Pegmatitos}

Os pegmatitos do Grupo Pinhal são corpos litológicos muito variáveis quanto à sua forma, espessura, contatos, estrutura e textura. Ocorrem não só no interior dos complexos granítico-migmatíticos, mas também em suas encaixantes. Vários desses corpos estão sendo minerados, principalmente na região de Inconfidentes, Bueno Brandão e Munhoz, para a extração de feldspato, quartzo e caolim.

Em relação à forma de ocorrência temos corpos retilíneos ou escalonados (cortando granitos e rochas encaixantes), tipos brechados (englobando fragmentos angulares das encaixantes), veios pegmatíticos irregulares (discordantes ou concordantes em relação às encaixantes) lentes, bolsð̃es, nódulos ou "schlieren" alongados (concordantes e discordantes), além de pegmatitos disruptos (através de "boudinage").

Quanto à sua espessura os pegmatitos variam desde centímetros até dezenas de metros. Seus contatos podem ser retilíneos, encurvados ou irregulares (sempre nítidos) ou então irregulares e difusos.

Quanto à estrutura são simples ou complexas e, neste caso, podem exibir zona central de granulação mais grossa de quartzo, feldspato ou ambos; um núcleo ou zonas marginais 
aplíticas; zonas marginais enriquecidas em biotita ou hornblenda; septos de rochas encaixantes na porção central; concentraçбes marginais de opacos; fragmentos de rochas encaixantes assimilados ou não; núcleos de minerais máficos em lentes e bolsðes; contatos difusos, ressaltados pela presença de megacristais de microlina nas rochas encaixantes; pegmatitos nodulares irregulares formados pela coalescência de megacristais em gnaisses e pegmatitos com zona central de granulação mais fina.

Quanto à textura observam-se casos de cristais com disposição caótica, perpendicular ou paralela aos contatos dos diques tabulares ou lentes concordantes, ovaladas. Em alguns casos a orientação paralela está restrita às zonas marginais dos corpos e, mesmo assim, de maneira incompleta. Quando os corpos se situam nas abas das dobras, os máficơs podem exibir disposição paralela à xistosidade plano-axial. Outras vezes os máficos (notadamente a biotita) formam agregados alongados, paralelos à xistosidade das encaixantes.

As formas, contatos, estruturas e textura dos pegmatitos revelam a presença de várias geraçбes, comprovada no campo, pela intersecção de pegmatitos com características distintas. Assim, existem corpos pré-, sin- e pós-tectôni$\cos$ em relação às diversas fases magmáticas $\mathrm{e}$ deformacionais presentes nos complexos granitico-migmatíticos. Os vários tipos de pegmatitos podem ser dispostos segundo uma sequeência na qual a diferença de plasticidade entre o pegmatito e as encaixantes varia continuamente; uma extremidade da seqüência é representada pelos pegmatitos brechados e a outra pelos veios disruptos.

\section{RELAÇÃO ESPACIAL ENTRE OS GRANITOIDES}

Todos os tipos de granitóides acima descritos ocorrem tanto em grandes áreas (com feiçбes homogêneas) quanto em associaçбes íntimas em que os contatos são nítidos ou difusos. Exemplos desta associação intima dos diferentes tipos de granitóides estão representados no mapa da Fig. 3, o que demonstra sua complexa evolução e a dificuldade do seu mapeamento.

\section{A ESTRUTURA DOS COMPLEXOS}

Os complexos granítico-migmatíticos do Grupo Pinhal são compostos por granitos formadores de migmatitos, granitos não formadores de migmatitos, migmatitos (no sentido de HÄRME, 1965) e intercalações mais ou menos volumosas de rochas do Grupo Amparo, que localmente passam a constituir a litologia predominante (Fig. 4). Em torno do primeiro tipo de granitos desenvolve-se com freqüência uma auréola de migmatitos, constituída por 3 zonas com tipos estruturais distintos. A zona externa é formada por migmatitos acamados, nos quais o neossoma granítico é muitas vezes pegmatóide; a zona intermediária engloba migmatitos agmatíticos, de "schollen" (placas) e "schlieren"; e a zona central é composta de migmatitos "schlieren", nebulíticos e homofânicos. Essa zona central exibe contatos gradacionais em relação ao núcleo granítico, o qual pode ser equigranular ou porfiróide (Fig. 4).

A espessura de cada zona migmatítica é variável, podendo mesmo faltar. $\mathrm{Na}$ auréola, como um todo, a espessura varia desde dezenas até milhares de metros. A seqüência das zonas pode ser alterada pela falta de uma delas, por falhamento, pela intrusão de granitos não formadores de migmatitos (que geralmente penetram ao longo de fraturas e falhas), ou por interferência de auréolas migmatíticas de granitos contíguos, o que leva ao desenvolvimento de migmatitos complexos, polifásicos.

A seqüência dos tipos estruturais de migmatitos na auréola obedece a um esquema lógico. Os migmatitos acamados da zona externa resultam da injeção de fraçôes magmáticas da intrusão; e como estas são enriquecidas em voláteis que the conferem elevada fluidez e pressão, fica facilitada a sua penetração ao longo dos planos de foliação e de outras fraquezas da rocha encaixante. A proporção paleossoma: neossoma dos migmatitos acamados é muito variável, com predominância de um ou do outro. Como o neossoma também está enriquecido em álcalis, é comum observar-se, no paleossoma invadido, reaçб̃es do tipo piroxênio $\rightarrow$ anfibólio $\rightarrow$ micas $\rightarrow$ clorita, indicando a adição de álcalis ao sistema (WERNICK e PENALVA, 1976). O processo é acompanhado pela recristalização de uma fina faixa do paleossoma diretamente em contato com o neossoma a qual se mostra enri- 


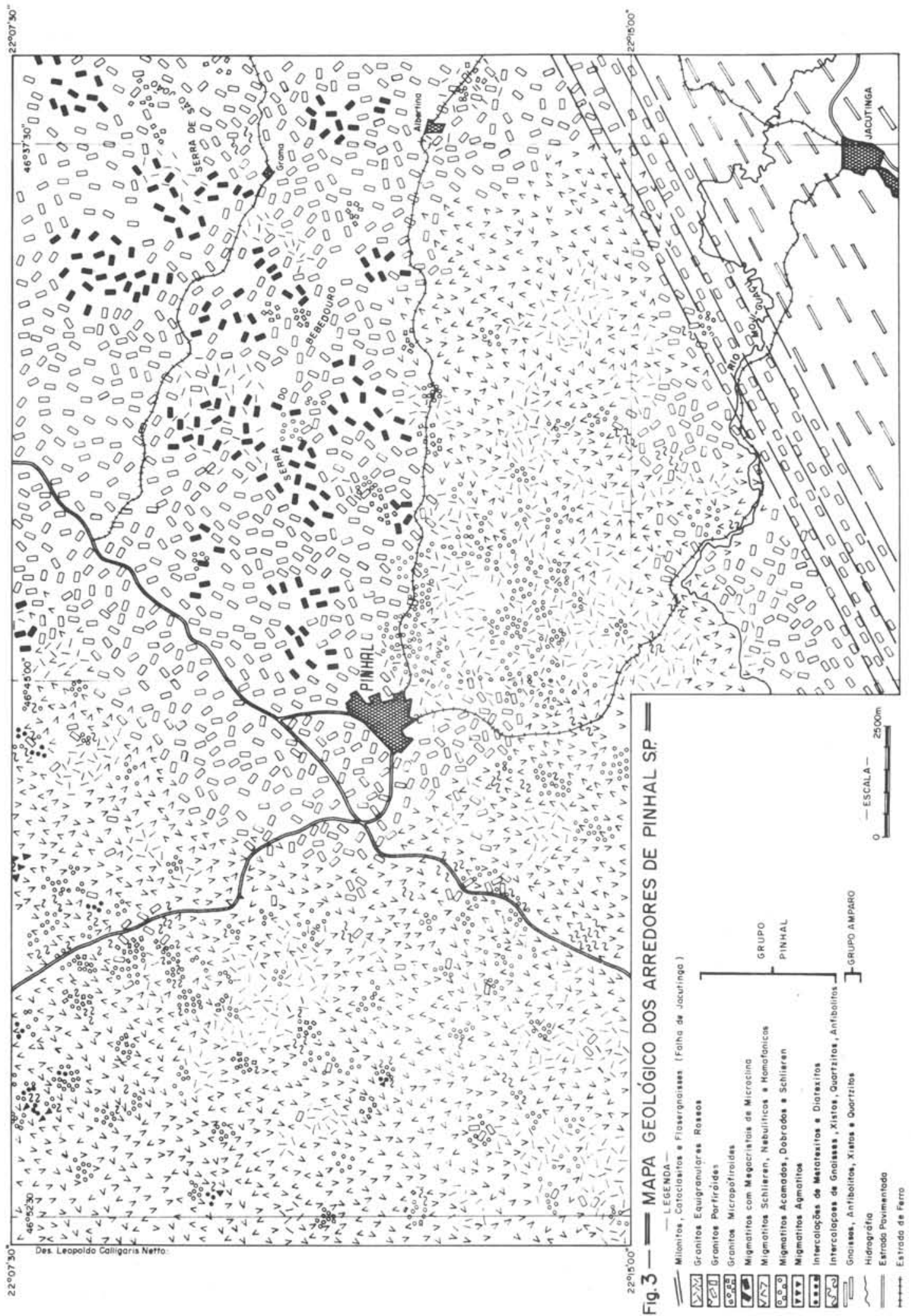


quecida em máficos. Isto denota a segregação de certa taxa de quartzo e feldspato do paleossoma para o interior do neossoma. Outra transformação mineralógica observada é a passagem da biotita para almandina, cordierita ou mesmo sillimanita (HARME, 1965).

$\mathrm{Na}$ zona intermediäria o esforço direto exercido pelo magma sobre as encaixantes provoca a sua fragmentação em blocos, placas e fragmentos com formas e dimensб̋es variáveis, que são englobados pelo magma granítico. Essa fragmentação atinge indistintamente tanto os tipos litológicos maciços (e. g. anfibolitos) quanto os tipos foliados (e. g. gnaisses). Também aqui ocorrem freqüentes transformaçס̄es mineralógicas, com o desenvolvimento de bordas de reação, a assimilação parcial das encaixantes. Igualmente ocorre a invasão de numerosos veios e filetes, milimétricos a centimétricos de neossoma, ao longo dos quais se observam todas as feiçбes descritas para os migmatitos acamados além da formação de estictólitos. À semelhança dos migmatitos acamados, nos outros diferentes tipos de migmatitos também pode ocorrer, na zona intermediária, o predomínio do paleossoma ou do neossoma.

$\mathrm{Na}$ zona central, dado o amplo predomínio de material granítico, as rochas encaixantes são intensamente penetradas pelo magma, resultando em sua assimilação quase completa, com a formação de migmatitos "schlieren", nebulíticos (ricos em estruturas reliquiares), "fantasmas", (só visíveis nos casos em que a rocha esteja molhada) e homofânicos, (cuja distinção do granito do núcleo é, em geral, dificultosa). Os migmatitos nebulíticos e homofânicos correspondem aos granitos metassomáticos descritos por SIMONEN (1948) na região de Aulanko, SW da Finlândia. O primeiro sinal da granitização é a ocorrência de delgados filmes contendo plagioclásio, quartzo e muita microclina, que penetram entre os cristais das rochas encaixantes. Com a intensificação do processo, o teor de hornblenda primária nas encaixantes diminui, devido sua transformação em biotita. Nos estágios mais avançados de assimilação a hornblenda chega a faltar completamente, observando-se apenas agrupamentos de biotita, que são possivelmente seus relictos; o teor destes também diminui progressivamente. $\mathrm{O}$ plagioclásio zonado dos gnaisses assimilados torna-se turvo e mais albítico, mas suas caracte- rísticas primárias (formas e dimensões) são preservadas. A rocha é, também, retalhada por delgados veios aplíticos, ricos em microclina, em que os contatos são difusos em relação à rocha assimilada. Finalmente, em toda a rocha ocorre um profuso desenvolvimento de cristais de microclina, o que confere à rocha assimilada uma textura sucessivamente mais homogênea, magmática (WERNICK e PENALVA, 1976).

\section{METASSOMATOSE}

A Fig. 4 mostra, esquematicamente, a superfície de erosão idealizada de um complexo granítico-migmatítico do Grupo Pinhal, com seus granitos formadores de migmatitos, granitos não formadores de migmatitos e enclaves de rochas metamórficas do Grupo Amparo (os quais localmente podem constituir a litologia predominante).

Nos complexos o processo de migmatização é acompanhado por fenômenos metassomáticos mais ou menos intensos, que afetam não só os migmatitos mas também os enclaves gnaíssicos; esse metassomatismo é de natureza potássica ou sódica.

\subsection{Metassomatismo Potássico}

É caracterizado por adição de potássio ao sistema rochoso afetado, resultante em profuso desenvolvimento de cristais de microclina, diminutos, ou formando megacristais ovalados, irregulares ou retangulares que atingem até $15 \mathrm{~cm}$ de comprimento. A microclina se desenvolve às custas do plagioclásio e o processo é acompanhado pela destruição dos máficos pobres em potássio, ao longo da seqüência piroxênio $\rightarrow$ mica $\rightarrow$ clorita. As variações químicas que caracterizam o processo foram descritas por WERNICK e GOMES (1976).

A quantidade, forma, dimensбes e orientação dos megacristais nos gnaisses feldspatizados dependem da estrutura regional das rochas encaixantes dos complexos, bem como da estrutura, composição e textura das rochas afetadas no seu interior. WERNICK (1972 a) mostrou para o Maciço de Morungaba, que a quantidade de megacristais por $\mathrm{m}^{2}$ aumenta sucessivamente para o interior do complexo e que as linhas de isoconcentração de megacristais dispõem-se paralelamente à estrutura regional. Já 


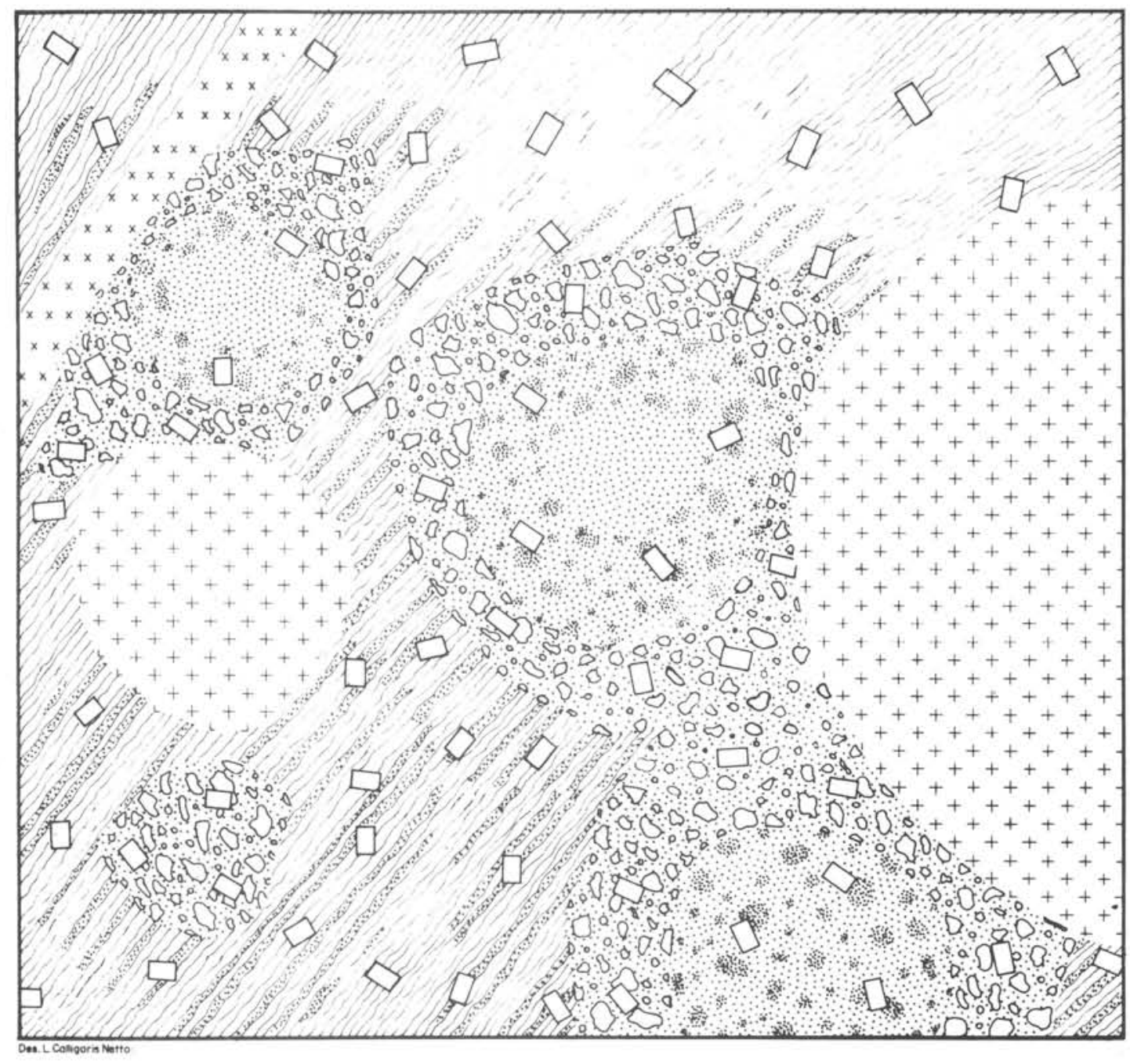

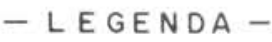

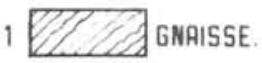

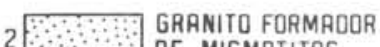
DE MIGMATITOS.

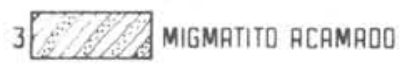

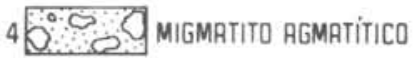

5 MIGMRTITO NEBULITICO

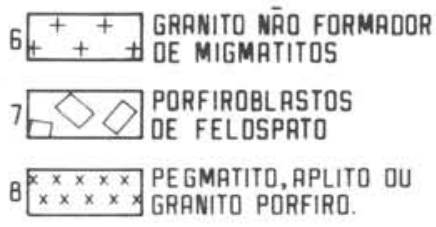

$6 t_{+}^{+}++$GRANITO NR̄O FORMADOR

$7 \bigcirc \bigcirc$ PORFIROBLASTOS

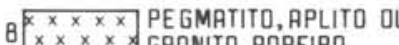

GRANITO PORFIRO.

Fig. 4 - ESQUEMA IDEALIZADO DE PARTE DE UM MEGADIAPIRO DO GRUPO PINHAL. 
WERNICK et al. (1976), estudando rochas foliadas e maciços feldspatizados do Complexo Socorro, mostraram a influência de suas estruturas na quantidade, forma, dimensőes e orientação dos megacristais desenvolvidos, e concluíram pela existência de vários impulsos metassomáticos no complexo. Cada impulso está ligado a uma das várias fases de intrusão e tectonismo que ocorreram no complexo e que geraram, sucessivamente, novos gradientes térmicos, químicos e de pressão que levaram ao desenvolvimento de várias fases de feldspatização.

\subsection{Metassomatismo Sódico}

O metassomatismo sódico é muito menos freqüente e menos intenso que o potássico nas rochas do Grupo Pinhal, sendo caracterizado por uma albitização das rochas afetadas pelo fenômeno. O processo caracteriza-se por uma epidotização, parcial ou total, dos plagioclásios dos gnaisses. Paralelamente observa-se uma progressiva diminuição no teor de microclina presente na rocha, em alguns casos chegando a faltar totalmente. Resultam, desta maneira, rochas constituídas apenas por albita, epidoto e clorita. O plagioclásio é praticamente albita pura, ocorrendo associada com epidoto (como relicto do placioclásio primário) ou formando manchas e agregados de cristais radiais; estes indicam crescimento a partir de material novo adicionado ao sistema rochoso. Minúsculas inclusões de opacos são visíveis na albita.

O quartzo ocorre também sob forma de 2 tipos de grãos. Os maiores, arredondados, parecem ser relictos dos gnaisses originais, enquanto que indivíduos diminutos (algumas vezes exibindo faces cristalinas bem desenvolvidas) cristalizaram-se em conexão com o metassomatismo sódico.

Epidoto ocorre como produto de alteração do plagioclácio primário dos gnaisses. Algumas vezes ocorre associado a biotita e clorita (na ausência de albita) com formas pseudomórficas de hornblenda. A biotita é castanha e ocorre sob forma de "fiapos" irregulares. Apatita e pequenos grãos de opacos são os acessórios principais.

A albitização é um processo posterior ao metassomatismo potássico inicial. Esta seqüência é caracterizada pela existência de gnaisses com megacristais de microclina, envolvidos por uma capa de albita. Tal fato revela, de modo nítido, a existência de um fracionamento dos álcalis durante a fase metassomática, que se iniciou pela etapa potássica, seguida ou não por uma etapa posterior, de natureza sódica.

\section{MECANISMO DE INTRUSÃO}

Os complexos granítico-megmatíticos do Grupo Pinhal correspondem a megadiápiros formados pelo conjunto de várias intrusð̃es ou complexos polidiapíricos (WERNICK e PENALVA, 1978). São feições indicativas desse fenômeno:

a) A sua forma global, arredondada e ovalada.

b) A presença, localmente, de um sinclinal marginal ("rim syncline"), (Fig. 5, I-D e II-D).

c) Lineações verticais a subverticais nas encaixantes, nas intercalações gnaíssicas e nos granitos dos complexos; a ocorrência de lineaçбеs que mergulham para SE, S, SW parece indicar que os diápiros não tiveram uma ascensão puramente vertical, mas sofreram a ação de esforços subhorizontais (CLOOS, 1948) dirigidos para $\mathrm{N}$, resultante num basculamento do Complexo Socorro durante sua penetração (Fig. 5, I-B e II-B).

d) Dobramento de diques nas rochas encaixantes, indicativo, ao menos parcialmente, de uma tectônica de balão ("baloon tectonic", de RAMSAY) ligada à intrusão do complexo.

e) A ocorrência, nos complexos, de várias intrusões envolvidas por auréolas migmatíticas.

f) A ocorrência de intrusões formadoras ou não de migmatitos, indicando a existência, nos complexos, de várias fases intrusivas e tectônicas com características distintas, refletidas em vários impulsos metassomáticos (Fig. 5, IV).

g) A presença de estruturas de escorregamento mais ou menos desenvolvidas no sinclinal marginal (Fig. 5, I-C).

h) A presença, em maior ou menor extensão, de uma zona de pegmatitos contornando parte dos complexos (HARALYI, 1964; WERNICK, 1967 e 1977 a).

$\mathrm{O}$ desenvolvimento e penetração dos megadiápiros devem estar ligados a uma ampla e $14-$ 


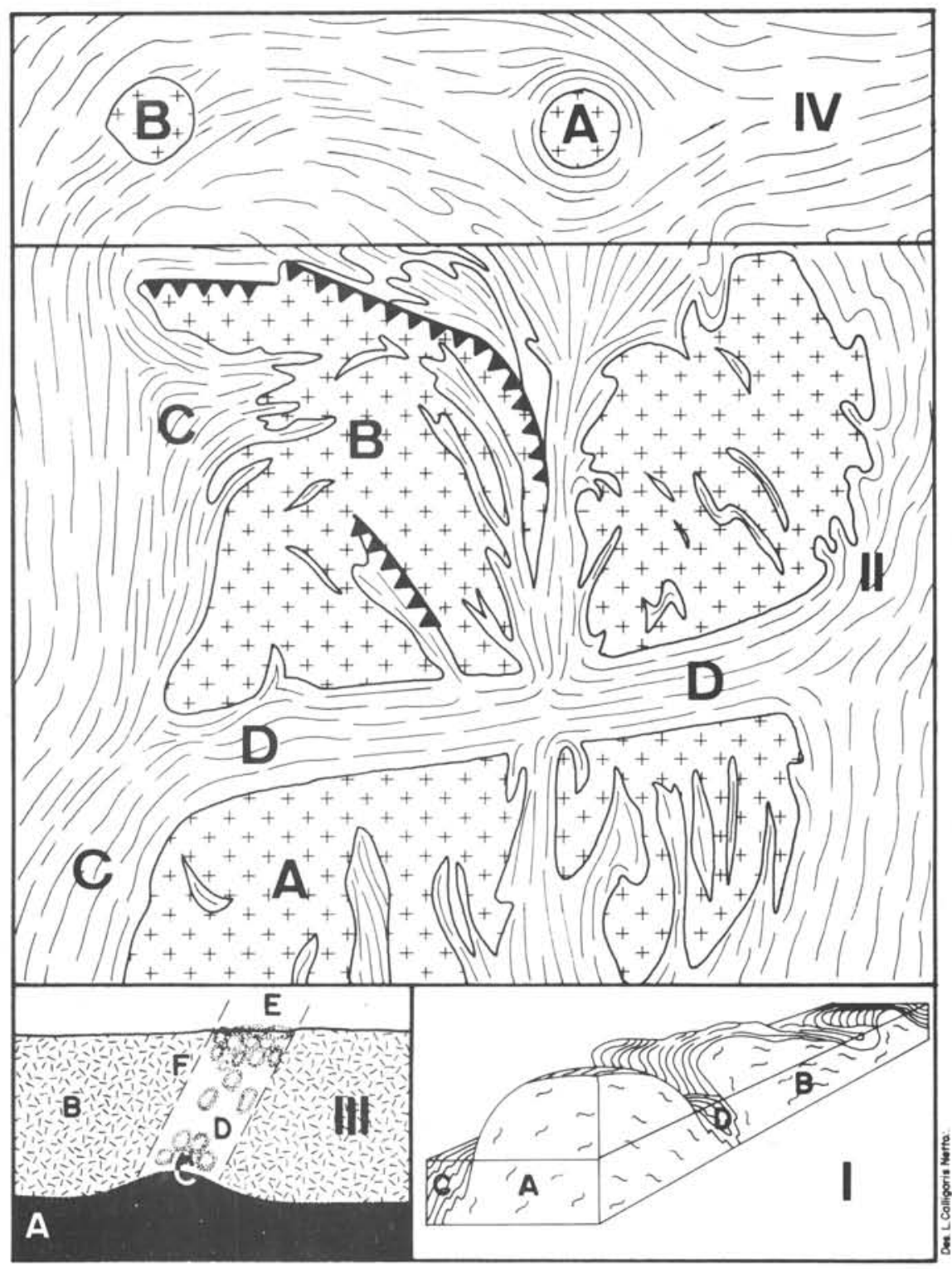

Fig. 5 - I-Penetraçōo de megadiapiros: A - Diapiro com ascençāo vertical; B Diapiro bosculado; C-Rochas encaixantes com lineaçðes verticais e estruturas de escorregamento; D-Sinclinal marginal.

II - Planto de blocodiagramo I. Letras com o mesmo significado. Observar as falhas de empuräo no diapiro basculado.

III-Penetração de megadiapiros ao longo de canais térmicos ligados a zonas rupteis: A-Manto; B - Crosta sialica; C-Locus magmatogênico ( parte infe_ rior da crosta com alguma contribuiçōo do manto); E - Megadiapiro polidiapirico; $\mathrm{F}$ - Zona ruptil associada a canal térmico.

IV - Feiçōes in dicativas da continuidade do processo intrusivo: A-Granito deformando estruturas; B - Granito cortando estruturas. 
tou toda a faixa leste do Brasil durante o Ciclo Brasiliano. Esta fase é caracterizada por um metamorfismo de baixa a média pressão (WERNICK e PENALVA, 1976; GOMES e WERNICK, 1976; MELLO e MELLO, 1974) atestada pela presença de minerais críticos e uma intensa remobilização. Esta afetou o embasamento numa extensão equivalente, ou mesmo superior, à área de rochas cogenéticas geradas no evento tecto-orogênico brasiliano. A existência de focos térmicos, intensos e duradouros, permitiu o desenvolvimento de "canais térmicos" (RAMBERG, 1952 e 1970; ELDER, 1970), ao longo dos quais penetram sucessivas intrusões granitóides, de acordo com o esquema da Fig. 5, III. Os canais térmicos situaram-se preferencialmente ao longo de grandes alinhamentos tectônicos; é o caso, por exemplo, dos Complexos Gaúcho e Pedras Grandes, ligados à zona tectônica do Canguçu (WERNICK e PENALVA, 1978), e do grande Complexo granítico-migmatítico linear, que corresponde ao Grupo Serra dos Órgãos, no Estado do Rio de Janeiro. A formação dos granitóides ocorreu a grandes profundidades, na base da crosta siálica, como revelaram estudos geocronológicos e de elementos-traços (CORDANI e KAWASHITA, 1971; WERNICK e GOMES, 1976) de acordo com a Fig. 5, III. O magma foi essencialmente anidro, como bem revela o caráter epizonal de muitos corpos, com sua relativa pobreza em pegmatitos.

Durante sua longa ascenção, os granitóides passaram por sucessivas variaçōes ambientais (de natureza térmica, química, de pressão e concentração de voláteis), resultando em várias remobilizaçōes, recristalizaçóes em estado sub-sólido, assimilação e fenômenos metassomáticos diversos (PICADA, 1967), sem que houvesse mudança substancial do seu caráter químico inicial (GOMES e WERNICK, 1976;WERNICK, 1978 b).

\section{GEOCRONOLOGIA}

Dados $\mathrm{Rb} / \mathrm{Sr}$ e $\mathrm{K} / \mathrm{Ar}$ indicam para os complexos granítico-migmatíticos do Grupo Pinhal uma evolução complexa, polifásica, com idades referíveis ao Ciclo Brasiliano (CORDANI e BITTENCOURT, 1967; EBERT e BROCHINI, 1968; DELHAL et al., 1969; CORDANI e KAWASHITA, 1971; MINIOLI, 1971; HASUI e
HAMA, 1972; CORDANI, 1973; CORDANI et al., 1973; OLIVEIRA, 1973; WERNICK et al., 1976; HAMA e CUNHA, 1977). Os dados fornecidos por estes autores indicam a formação complexa para o magma granítico (na base da crosta, com a contribuição do manto), e que a penetração dos diversos corpos granitóides se estendeu por um longo período de tempo, acompanhada por evidentes fenômenos metassomáticos.

\section{CORRELAÇÃO ESTRATIGRÁFICA}

Evidências geológicas, petrográficas, estruturais e geocronológicas permitiram a WERNICK (1978 a) correlacionar o Grupo Pinhal com o Grupo Serra dos Orgãos, no sentido que the foi dado por DELHAL et al. (1969) e CORDANI et al. (1973) e que corresponde à "zona central granítico-migmatítica"dos Paraíbides, na concepção de EBERT (1968).

\section{CONCLUSÕES}

Os autores definem e apresentam as principais características do Grupo Pinhal na porção NE do Estado de São Paulo e áreas vizinhas do Estado de Minas Gerais, concluindo:

A) O Grupo Pinhal corresponde a uma associação litológica formada por granitóides plutônicos e hipo-abissais variados, migmatitos e diversos tipos de rochas metamórficas.

B) Esta litologia constitui grandes complexos, que correspondem a megadiápiros intrusivos em rochas metamórficas mais antigas.

C) A caracterização da natureza diapírica dos complexos é possível através de dados geológicos, estruturais e litológicos.

D) A penetração dos megadiápiros ocorreu durante o Ciclo Brasiliano, através de intrusøes múltiplas ao longo de "canais térmicos" associados, com freqüência, a amplos alinhamentos tectônicos.

E) Os complexos granítico-migmatíticos são formados por granitos formadores de migmatitos, granitos não formadores de migmatitos e intercalaçб̃es mais ou menos extensas de 
rochas metamórficas. Os granitos formadores de migmatitos são rodeados por uma auréola de migmatitos, com espessura variável e, em geral, composta por três zonas, contendo tipos estruturais distintos.

F) As auréolas raramente são perfeitas. São comuns perturbaçбes devidas a falhamentos, pela omissão de uma ou mesmo duas zonas, pela penetração de granitos não formadores de migmatitos, além de basculamento e rotação de blocos tectônicos em épocas mais modernas.

G) Em virtude da interferência de auréolas migmatíticas contíguas ocorreu o desenvolvimento de migmatitos complexos, polifásicos.

H) As intrusões graníticas e a formação de migmatitos foram acompanhadas por várias fases de metassomatismo potássico e sódico, que afetaram tanto os migmatitos como os enclaves gnaisses. A metassomatose sódica é menos intensa que a potássica, foi posterior a esta e demonstra ter havido um fracionamento dos álcalis durante os fenômenos metassomáticos.

I) Os granitóides do Grupo Pinhal são de origem profunda, com freqüência formados a partir de magmas anidros. Durante sua ascenção sofreram várias modificações, tais como remobilização, recristalização sub-sólida, metassomatose e assimilação, sem que houvesse alteração substancial no seu caráter original.

J) Observando-se as reaçoes entre os materiais granitóides de idades transamazônica e brasiliana, não só na região estudada mas também em toda porção oriental do Brasil, nota-se que as rochas referíveis ao Ciclo Brasiliano são muito mais abundantes, seja como neossoma em migmatitos ou formando grandes e nume- rosos batólitos ou ainda representando um embasamento mais antigo intensamente remobilizado. Tal fato sugere que o Ciclo Brasiliano caracterizou-se, em especial, por agregar à crosta abundante material granítico, originado a partir do manto ou pela reciclagem de material crustal mais antigo.

L) Os principais recursos econômicos ligados ao Grupo Pinhal são representados por material de construção (granitos equigranulares, saibro, areias) e pegmatitos, presentes nos complexos e nas suas rochas encaixantes.

M) O Grupo Pinhal é correlacionável ao Grupo Serra dos Órgãos (RJ). Os complexos granitóides que os integram podem ser classificados como tele-orogênicos, em conseqüência de sua localização em relação à região de Dobramentos Sudeste (ZARIDZE, 1969, 1975).

N) A definição do Grupo Pinhal obedeceu aos preceitos do Código Estratigráfico e a esta unidade lito-estratigráfica devem ser referidos outros complexos granítico-migmatíticos existentes no Estado de Minas Gerais, a leste dos Complexos Pinhal e Socorro.

\section{AGRADECIMENTOS}

Os autores agradecem ao "staff" do Departamento de Mineralogia e Recursos Minerais do Instituto de Geociências e Ciências Exatas da Universidade Estadual Paulista - Campus de Rio Claro - atualmente desenvolvendo vários projetos de pesquisa na região estudada no presente trabalho, pelas críticas e sugestбes que nos foram apresentadas. Agradecemos ainda ao $\mathrm{CNPq}$ pelo suporte financeiro dado para a execução da presente pesquisa.

\section{BIBLIOGRAFIA}

ALMEIDA, F. F. M. de; HASUI, Y e BRITO NEVES, B. B. de - 1976 - The Upper Precambrian of South America. Bol. Inst. Geoc., USP, $7: 45-80$.

BETTENCOURT, J. da S. (Coordenador) - 1978 - "Projeto Pouso Alegre", Relatório Final. Convênio D. N. P. M. F. F. C. L. de Rio Claro..*

BRITO NEVES, B. B. de - 1975 - Regionalização geotectônica do Précambriano nordestino. Inst. Geoc., USP, tese. 
CLOOS, E. - 1946 - Lineation, a critical review and annotated bibliography. Geol. Soc. of Am., Mem. 18.

CORDANI, U. G. - 1973 - Evolução geológica pré-cambriana da faixa costeira do Brasil entre Salvador e Vitória. Inst. Geoc., USP, tese.

CORDANI, U. G. e BITTENCOURT, I. - 1967 - Determinação de idade potássio-argônio em rochas do Grupo Açungui. An. XXI Congr. Bras. Geol., : 218-233, Curitiba.

CORDANI, U. G. e KAWASHITA, K. - 1971 - Estudo geocronológico pelo método Rb-Sr de rochas graníticas intrusivas no Grupo Açungui. XXV Congr. Bras. Geol., 105-110, São Paulo.

CORDANI, U. G. e DELHAL, J. e LEDENT, D. - 1973 - Orogenese superposées dans le Precambrian du Brésil sud-oriental (Etats de Rio de Janeiro et de Minas Gerais). Rev. Bras. Geoc., 3 (1) : 1-22.

DELHAL, J., LEDENT, de; CORDANI, U. G. - 1969 - Ages $\mathrm{Pb} / \mathrm{U}, \mathrm{Sr} / \mathrm{Rb}$ et $\mathrm{Ar} / \mathrm{K}$ de formations metamorphiques et granitiques du sudest du Brésil (états de Rio de Janeiro et de Minas Gerais). Annal. Soc. Geol. Belgique, $92: 271-283$.

EBERT, H. - 1968 - Ocorrência da fácies granulítica no sul de Minas Gerais e em áreas adjacentes, em dependência da estrutura orogênica: hipóteses sobre sua origem. An. Acad. Bras. Ciênc., 40 (supl.) : 215-229.

ELDER, J. W. - 1970 - Quantitative laboratory studies of dynamical models of igneous intrusion. In "Mechanism of Igneous Intrusion" (Ed. G. Newall e N. Rast), Gallery Press, Liverpool: 245-260.

EBERT, H. - 1971 - Os Paraibides entre São João del Rei, Minas Gerais e Itapira, São Paulo, e a bifurcação entre Paraibides e Araxaídes. Soc. Bras. Geol. (Núcleo São Paulo), Bol. Esp. 1 (Res. Com. XXV Congr. Bras. Geol.) 177-178, São Paulo.

EBERT, H, - 1974 - O Grupo Eleutério e a falha de Jacutinga (nordeste de São Paulo). Soc. Bras. Geol. (Núcleo Rio Grande do Sul), Bol. Esp. 1 (Res. Comun. XXVIII Congr. Bras. Geol.) : 726-730, Porto Alegre.

EBERT, H. e BROCHINI, M. F. - 1968 - Estudos estratigráficos e geocronológicos no Escudo Cristalino Brasileiro. Ciência e Cultura, $20: 621-625$.

FRANCO, R. R. e COUTINHO, J. M. V. - 1957 - Charnockitos e rochas associadas no Município de Amparo e Socorro, Estado de São Paulo. An. Acad. Bras. Ciênc., 28 (3) : 303-311.

GOMES, C. B.; COUTINHO, J. M. V. e OLIVEIRA, A. B. - 1966 - Paragasita em dolomitos metamórficos do Município de Tapiratiba, SP. An. Acad. Bras. Ciênc., $38: 39-46$.

GOMES, C. B.; RUBERTI, E. e WERNICK, E. - 1976 - Caracterização química de felspatos de rochas graníticas. An. Acad. Bras. Ciênc., 48 (3) : 445-452.

HAMA, M. - 1977 - Programa geocronológico do Projeto Sapucaí (Relatório interpretativo). Convênio CPRM-IGUSP/GEOCRON. Superintendência de São Paulo da CPRM (inédito).

HAMA, M. e CUNHA, H. C. S. - 1977 - Considerações sobre a idade da Formação Pouso Alegre e dos granitos Pós-Cambrianos da região sul do Estado de Minas Gerais e nordeste do Estado de São Paulo. Soc. Bras. Geol. (Núcleo São Paulo); Bol. do Prog. e Res. do 1ㅇ. Simp. Geol. Regional : 6, São Paulo.

HARALYI, N. H. - 1964 - Uma nova zona de feldspato - quartzo em São Paulo-Minas. Min. Met., 40 (238) : 181-182.

HASUI, Y. e HAMA, M. - 1972 - Geocronologia do Grupo São Roque pelo método potássio-argônio. Rev. Bras. Geoc., 2 (1): 8-24.

HASUI, Y.; CARNEIRO, C. R. e COIMBRA, A. M. - 1975 - The Ribeira Folded Belt. Rev. Bras. Geoc., 5 (3) : 257-266.

HARME, M. - 1965 - On the potassium migmatites of southern Finland. Bull. Comm. Géol. Finlande, $219: 1-43$.

LEONARDOS JR., O. H.; DUNHAM, A. C.; PIRES, F. R. M. e FORMAM, J. M. A. - 1971 - Nota sobre a Formação Pouso Alegre. An. Acad. Bras. Ciênc., 43 (e) : 131-134. 


\section{O GRUPO PINHAL NA REGIÃO NORDESTE DO ESTADO DE SÃO PAULO E AREAS VIZINHAS}

MEHNERT, K. R. - 1968 - Migmatites and the origin of granitic rocks. Elsevier Publ. Comp., New York.

MELLO, A. A. de e MELLO, Z. F. de - 1974 - Metamorphic zoning in the Seridó Region, northeastern Brazil. Rev. Bras. Geoc., 4 (1) : 1-14.

MINIOLI, B. - 1971 - Determinações potássio-argônio em rochas localizadas no litoral norte do Estado de São Paulo. An. Acad, Bras. Ciênc., 43 (2) : 443-448.

OLIVEIRA, M. A. F. de - 1973 - Petrologia das rochas metamórficas da região do São José do Rio Pardo, SP. Rev. Bras. Geoc., 3 (4) : 257-278.

OliVEIRA, M. A. F. de e HYPOLito, R. - 1973 - Rochas calco-silicáticas da região de São José do Rio Pardo, SP. An. XXVII Congr. Bras. Geol. $1: 193-200$, Aracaju.

OLIVEIRA, M. A. F. de e ALVES, F. R. - 1974 - Geologia e petrografia da região do Caconde, SP. An. XXVII Congr. Bras. Geol., 5 : 133-143, Porto Alegre.

OLIVEIRA, M. A. F. de e ALVES, F. R. - 1976 - Wollastonita em associações cálcicas da fácies granulito, Caconde, SP. Rev. Bras. Geoc. 6 (1) : 43-52.

PENALVA, F. e WERNICK, E. - 1973 - Compartimentação tectônica em parte do pré-cambriano paulista. Soc. Bras. Geol (Núcleo Bahia), Bol, Esp. 1 (Res. Com. XXVII Congr. Bras. Geol.) : 128-129, Aracaju.

PICADA, R. S. - 1967 - Estudos preliminares sobre a evolução e mineralogia do maciço granítico Encruzilhada. Esc. Geol., U. F. R. G. S., Publ. Espec. 14.

PIRES, F. R. M.; LEONARDOS JR., O. H. e PARENTI COUTO, J. G. - 1970 - Gonditos na região de Pouso Alegre, Minas Gerais. Min. Met., 52 (312) : 237-239.

RAMBERG, H, - 1952 - The origin of metamorphic and metasomatic rocks. The University of Chicago Press.

RAMBERG, H. - 1970 - Model studies in relation to intrusion of plutonic bodies. In "Mechanism of Igneous Intrusion" (Ed. G. Newall e N. Rast), Gallery Press, Liverpool : 261-286.

RODRIGUES, J. E. - 1976 - O Falhamento Transcorrente de Jacutinga, SP. Inst. Geoc., USP, tese.

SIMONEN, A. - 1948 - On the petrology of the Aulanka area in southwestern Finland. Bull. Comm. Géol. Finlande, $143: 1-66$.

SOARES, P. C. (Coordenador) - 1976 - "Projeto Caldas II", Relatório final. Convênio D. N. P. M. - F. F. C. L. de Rio Claro.*

WERNICK, E. - 1965 - Comunicaçāo preliminar sobre a geologia da quadrícula de Amparo, leste do Estado de São Paulo. D. N. P. M. - D. G. M., Bol., 44 (avulso) : 77.

WERNICK, E. - 1967 - A geologia da região de Amparo, leste do Estado de São Paulo. F. F. C. L. de Rio Claro, SP, tese.

WERNICK, E. - 1972 a - A geologia do maciço granítico de Morungaba, leste do Estado de São Paulo. Esc. Eng. São Carlos, USP, Bol. Geol., 16, 110 pp.

WERNICK, E. - 1972 b - Sobre a ocorrência de rochas calco-silicáticas nas proximidades de Duas Pontes, Município de Arcadas, leste do Estado de São Paulo. Ciência e Cultura, 24 (4) : 358-367.

WERNICK, E. - 1972 c - Granitos pórfiros dos arredores de Serra Negra, Valinhos e Amparo e suas relações com o maciço de Morungaba, leste do Estado de São Paulo. Rev. Bras. Geoc., 2 (2) : 129-138.

WERNICK, E. - 1977 a - Contribuição à estratigrafia do Pré-Cambriano do leste do Estado de São Paulo e áreas vizinhas. Rev. Bras. Geoc., 8 (2) : 206-216.

WERNICK, E. (Coordenador) - 1977 b - "Projeto Ouro Fino", Relatório final. Convênio D. N. P. M. - F. F. C. L. de Rio Claro.* 
WERNICK, E. - 1978 a - Contribuição à geologia do Maciço de Guaxupé, SP e MG. An. Acad. Bras. Ciênc., 50 (3) : 337-352.

WERNICK, E. - 1978 b - Cristalização fracionada na província granítica Ribeira, SP e PR. Soc. Bras. Geol. (Núcleo Nordeste): Bol. Esp. 1 (Res. Com. XXX Congr. Bras. Geol.) : 96.

WERNICK, E. e ARTUR, A. C. - 1974 - Petrofábrica de migmatitos dos arredores de Amparo, SP. Rev. Bras. Geoc., 4 (1): 27-39.

WERNICK, E. e FERNANDES, N. A. - 1972 - Triclinicidade de feldspatos potássicos de rochas graníticas do maciço de Morungaba, SP. An. XXVI Congr. Bras. Geol., $1: 51-56$, Belém.

WERNICK, E. e GOMES, C. B. - 1976 - Granitos e metamorfismo no vale do Ribeira de Iguape, SP e PR. An. XXVIII Congr. Bras. Geol., $5: 145-154$, Porto Alegre.

WERNICK, E. e GOMES, C. B. - 1977 - Geoquímica de maciços graníticos da região do Ribeira. Parte III: considerações petrológicas. An. Acad. Bras. Ciênc. 49 (1) : 157-169.

WERNICK, E. e PENALVA, E. - 1973 - Feições estruturais de migmatitos ao norte e sul da falha de Jacutinga, leste do Estado de São Paulo. Ciência e Cultura, 25 (supl.) (6) :183.

WERNICK, E. e PENALVA, F. - 1974 a - Migmatização e feldspatização de charnockitos e granulitos no leste paulista e sul de Minas Gerais. An. XXVIII Congr. Bras. Geol., 5 : 155-160, Porto Alegre.

WERNICK, E. e PENALVA, F. - 1974 b - Depósitos molassóides da Formação Eleutério, São Paulo-Minas Gerais. Soc. Bras. Geol. (Núcleo Rio Grande do Sul), Bol. Esp. 1 (Res. Com. XXVIII Congr. Bras. Geol.) : 723-726, Porto Alegre.

WERNICK, E. e PENALVA, F. - 1978 - Contribuição ao conhecimento das rochas granitóides do Sul do Brasil, Rev. Bras. Geoc., $8(3): 113-133$.

WERNICK, E.; FERNANDES, N. A. e ALMEIDA JR., N. F. de - 1976 a - Gonditos de Socorro e Itapira, SP. Min. Met. $39(372): 16-21$.

WERNICK, E.; OLIVEIRA, M. A. F. de ; KAWASHITA, K.; CORDANI, U. G. e DELHAL, J. - 1976 b - Estudo geocronológico pelo método $\mathrm{Rb} / \mathrm{Sr}$ em rochas do bloco Jundiaí e regiões adjacentes. Rev. Bras. Geoc., 6 (1) : $125-135$.

WERNICK, E.; PANTOJA, J. L. e NICOLA, J. P. - 1976 c - Megacristais do maciço granítico de Socorro (SP e MG). Soc. Bras. Geol. (Núcleo Minas Gerais), Bol. Esp. 1 (Res. Com. XXIX Congr. Bras. Geol.,) : 329, Belo Horizonte.

ZARIDZE, G. M. - 1969 - Granitoidbildung und Tektonik. Acta Geol. Acad. Scient. Hungar., 13 : 347-352.

ZARIDZE, G. M. - 1975 - Formation of granitoids in relation to tectonic structures. Krystalinikum, 11:115-122.

* Trabalho realizado pelo "staff de geólogos dos Departamento de Geologia Geral e Aplicada e de Mineralogia e Recursos Minerais do Instituto de Geociências e Ciências Exatas (I. G. C. E.) da Universidade Estadual Paulista "Júlio de Mesquita Filho"(U. N. E. S. P.) - Campus de Rio Claro, SP. 